\title{
Arsenic and Other Trace Elements in Five Edible Fish Species in Relation to Fish Size and Weight and Potential Health Risks for Human Consumption
}

\author{
Aleksandra Milošković, Vladica Simić* \\ Faculty of Science, University of Kragujevac, R. Domanovića 12, 34000 Kragujevac, Serbia \\ Received: 18 February 2014 \\ Accepted: 9 May 2014
}

\begin{abstract}
The main objectives of study were to determine the concentrations of As and other trace elements (Al, $\mathrm{Co}, \mathrm{Fe}, \mathrm{Ni}, \mathrm{Sn}, \mathrm{Se}$ ) in the muscle, liver, and gills of pikeperch (Sander lucioperca), catfish (Silurus glanis), and pike (Esox lucius), and in the muscle of Prussian carp (Carassius gibelio) and freshwater bream (Abramis brama), to identify relationships between element concentrations and total length and weight of the examined fish and studies of potential impact of contaminated fish consumption on human health. In the present study, the highest concentrations of As $\left(0.004 \mathrm{mg} \cdot \mathrm{kg}^{-1}\right)$, Sn $\left(0.154 \mathrm{mg} \cdot \mathrm{kg}^{-1}\right)$, and Co $\left(0.053 \mathrm{mg} \cdot \mathrm{kg}^{-1}\right)$ were observed in the liver of pikeperch. The highest concentrations of $\mathrm{Ni}\left(0.051 \mathrm{mg} \cdot \mathrm{kg}^{-1}\right)$ and Fe $\left(162.17 \mathrm{mg} \cdot \mathrm{kg}^{-1}\right)$ were observed in gills and liver of pike, respectively, while the highest concentrations of $\mathrm{Al}\left(22.65 \mathrm{mg} \cdot \mathrm{kg}^{-1}\right)$ and $\mathrm{Se}\left(0.509 \mathrm{mg} \cdot \mathrm{kg}^{-1}\right)$ were observed in gills and liver of catfish, respectively. Freshwater bream diverged from the other four species based on element concentrations in muscle, while catfish diverged from the other predator species based on element concentrations in gills. This indicates that the element levels detected in organs seem to reflect the pollution level of sediment and its biota, rather than the prevailing pollution state of the water. We recorded the most correlations between element accumulation and fish size and weight in the tissues of pike, which could probably be explained by life histories, as well as by habitat of this species. Meat of studied species should be safe for utilization in human diet.
\end{abstract}

Keywords: arsenic, reservoir, fish, food safety

\section{Introduction}

The rapid development of industry and agriculture has resulted in an increase in pollution and, therefore, contamination of aquatic ecosystems (e.g. lakes, reservoirs, rivers, streams, etc.) has been receiving increased worldwide attention over the last few decades. Metals are considered to be the most important form of aquatic pollution because of their toxicity, long persistence, and accumulation by

*e-mail: simic@kg.ac.rs aquatic organisms [1-3]. In addition to toxic elements (arsenic, As), essential trace elements (aluminum, Al; cobalt, $\mathrm{Co}$; iron, Fe; nickel, $\mathrm{Ni}$; tin, $\mathrm{Sn}$; and selenium, $\mathrm{Se}$ ) become toxic to living organisms when subjected to high concentrations [4].

Fish are constantly exposed to chemicals in polluted waters, so they could be used as excellent biological markers of elements in aquatic ecosystem [5]. Elements differ in their accumulation levels and patterns depending on fish species, as well as fish tissue $[6,7]$. Gills are the primary site of element uptake from water, especially if elements are 
bound to particulate matters [8], while the liver as metabolically active tissue (due to the presence of metal-binding proteins) is the accumulation location for elements [9, 10]. Muscles are not important tissue in metals agglomeration, except mercury, and the study of potential metals accumulations in this tissue of fish is justified because of human consumption [11]. However, since they are not always the best indicators of element contamination present in fish, the analysis of other tissues is recommended as well [12]. Also, element distribution between different tissues is determined mainly by their content in water and food, and therefore can serve as a pollution indicator of the environment [13].

Contaminated fish represent a potential risk for predatory fish, birds, and mammals that feed on them [14]. The pollutants accumulated by aquatic inhabitants (especially fish) subsequently transferred to humans through the food chain $[15,16]$ and it is generally accepted that consumption of fish and seafood is a major source of arsenic exposure for humans [17]. Because of high protein content and low saturated fats containing omega fatty acids and supporting good health and protecting the body against cardiovascular diseases, contaminated fish represent a serious food safety concern across the globe [18]. In recent years fish consumption has increased in Serbia primarily due to a public campaign on health benefits through popular media [19].
In general, health benefits and fish consumption are informed through different organizations but rarely is there insight into potential health risks [20-22]. Consequently, knowledge of element concentrations in fish is important both with respect to human consumption of fish and nature management [23].

Data and publications on element pollution in Serbia are still limited. Only a few studies on element content in organisms living in waters of Serbia have been carried out [6, 7, 24-27].

The main objectives of this study were:

(1) To determine the concentrations of As and other trace elements (Al, $\mathrm{Co}, \mathrm{Fe}, \mathrm{Ni}, \mathrm{Sn}, \mathrm{Se}$ ) in the muscle, liver and gills of pikeperch (Sander lucioperca), catfish (Silurus glanis), and pike (Esox lucius), and in the muscle of Prussian carp (Carassius gibelio) and freshwater bream (Abramis brama)

(2) To examine if there were differences in tissue accumulation in three predatory fish species

(3) To examine if there were differences in fish accumulation

(4) To assess the relationships between element concentrations and total length and weight of the fish

(5) To determine whether specific elements exceeded maximum permitted concentrations (MPC) for human consumption

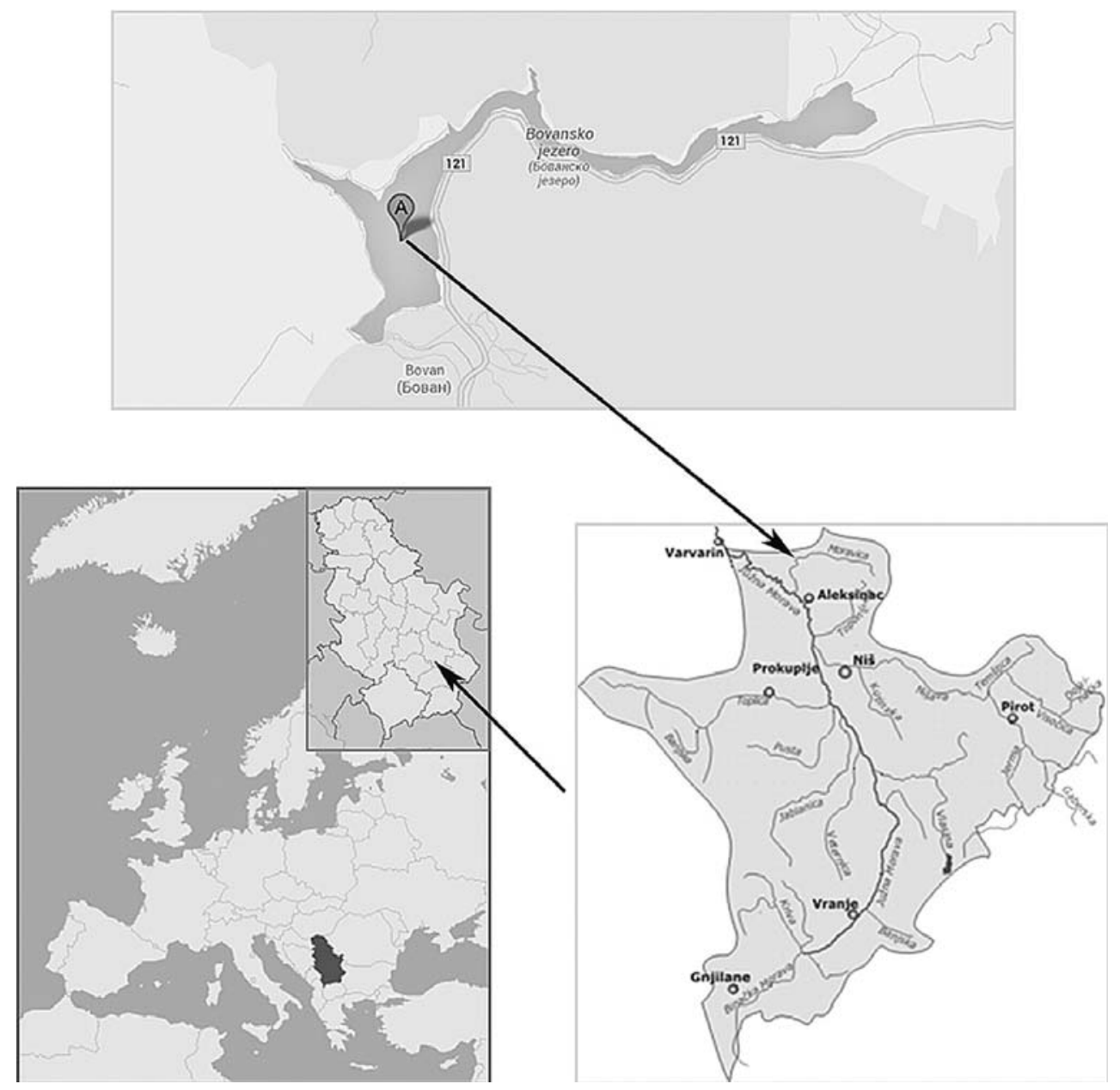

Fig. 1. Location map of the Bovan Reservoir near the city of Aleksinac, southeastern Serbia. 


\section{Material and Methods}

Bovan is an artificial reservoir situated in the middle flow of the Sokobanjska Moravica River near the city of Aleksinac (Fig. 1) in southeast Serbia. The Bovan Reservoir was planned as a multi-functional system, with the primary aim of regulating the basin of the Morava River and protecting the Đerdap I Reservoir [28].

This reservoir has been under a strong anthropogenic influence. Bovan Reservoir continuously receives significant amounts of nutrient-rich water from the Sokobanjska Moravica River due to the direct discharge of untreated domestic wastewater into the river. The land around the reservoir is intensively processed with the use of invasive agricultural measures (excessive use of pesticides, herbicides, and fungicides). Also, constantly expanding cottage settlements on the coastal area of the reservoir, which generally have no prescribed way to regulate the storage and discharge of wastewater, contribute to the pollution of the reservoir.

The field work was conducted during May 2012. Five fish species: pikeperch $(S$. lucioperca, $\mathrm{N}=13)$, catfish $(S$. glanis, $\mathrm{N}=10$ ), pike (E. lucius, $\mathrm{N}=10$ ), Prussian carp (Carassius gibelio, $\mathrm{N}=10$ ), and freshwater bream (Abramis brama, $\mathrm{N}=10$ ) were collected with portable lift nets of different lengths, widths, and mesh diameters. The select species were regular catches of fishermen in this area of Serbia. Pikeperch, catfish, pike, and freshwater bream are among the economically most valuable fish species and form the core of commercial fishing in reservoirs and rivers in Serbia (as well as Prussian carp, although it is a nonnative species [29]).

Specimens were sacrificed with a quick blow to the head, measured for their total body length $(\mathrm{cm})$ and weight $(\mathrm{g})$, and subsequently dissected. Mean values $( \pm \mathrm{SD})$ for total length and weight determined for species are pikeperch $44.6 \pm 7.5 \mathrm{~cm}$ and $722.7 \pm 348.8 \mathrm{~g}$; catfish $82.2 \pm 22$ $\mathrm{cm}$ and $4,650 \pm 3,934 \mathrm{~g}$; pike $55.2 \pm 8.5 \mathrm{~cm}$ and $779.6 \pm 179.3$ $\mathrm{g}$; Prussian carp $44.33 \pm 10.25 \mathrm{~cm}$ and $883.66 \pm 534.42 \mathrm{~g}$; and freshwater bream $33 \pm 3.04 \mathrm{~cm}$ and $585.33 \pm 213.71 \mathrm{~g}$. Samples of pikeperch, catfish, and pike were removed from gills, liver, and the right dorsal muscle, while samples of Prussian carp and freshwater bream were removed only from the right dorsal muscle. All samples were washed with distilled water, transferred to the laboratory, and stored at $-20^{\circ} \mathrm{C}$ prior to analysis.

In the laboratory fish samples $(\sim 1.5 \mathrm{~g})$ were dried in a lyophilizer (Christ Alpha 2-4 LD, Harz, Germany), and then digested in an Advanced Microwave Digestion System (ETHOS 1, Milestone, Italy) using a mixture of $65 \%$ nitric acid and 30\% hydrogen peroxide (Merck, Darmstadt, Germany, $10: 2 \mathrm{v} / \mathrm{v}$ ) at $220^{\circ} \mathrm{C}$ for $20 \mathrm{~min}$. After cooling to room temperature and without filtration, the solution was diluted to a fixed volume (volumetric flask, $25 \mathrm{ml}$ ) with ultra-pure water (Milli-Q system, Millipore, Bedford, MA, USA). Concentrations of $\mathrm{Al}$ and $\mathrm{Fe}$ were measured in fish tissues in triplicate using a Thermo Scientific iCAP 6500 Duo ICP-OES instrument (Thermo Fisher Scientific, Cambridge, United Kingdom). Co, Ni, Sn, As, and Se deter- mination in fish tissues was achieved with a Thermo Scientific iCAP Qc ICP-MS (Thermo Scientific, Bremen, Germany), with operational software Qtegra. Instrumental conditions were optimized to obtain sufficient sensitivity and precision. The potential presence of trace elements in chemicals used in sample preparation was resolved by using a number of blank samples. Standards for instrument calibration were prepared on the basis of multi element (SSLow Level Elements ICV Stock, $10 \mathrm{mg} / \mathrm{L}$ ) and mono element (Sn LSNH-100, $10 \mathrm{mg} / \mathrm{L} \mathrm{Sn)}$ certified reference solution ICP Standard (VHG Labs, Inc- Part of LGC Standards, Manchester, NH 03103 USA). DORM 4 (NRCC, Canada) standard reference material was analyzed for elements. The detection limits for $\mathrm{Al}$ and $\mathrm{Fe}$, analyzed by ICP-OES, were $0.1,0.05 \mathrm{mg} \cdot \mathrm{kg}^{-1}$, respectively and detection limits for $\mathrm{Co}$, $\mathrm{Ni}, \mathrm{Sn}, \mathrm{As}$, and Se, analyzed by ICP-MS, were 0.00005 , $0.007,0.00027,0.013,0.00001 \mathrm{mg} \cdot \mathrm{kg}^{-1}$, respectively.

All concentrations were expressed as $\mathrm{mg} \cdot \mathrm{kg}^{-1}$ wet weight (ww).

In order to assess significant differences between species and tissues, the non-parametric Kruskal-Wallis test was applied. Post hoc inter-group comparisons of element levels were performed by the non-parametric MannWhitney test for two independent samples. Correlations between the biological variables size and weight in relation to concentration of elements in species were evaluated by Spearman correlation. The level of significance was set at a probability lower than $0.05(\mathrm{p}<0.05)$. All statistical analysis of data was carried out using SPSS 16.0 statistical package programs for Windows (SPSS Inc., Chicago, IL, USA).

All obtained element levels in the studied fish were compared with maximum permitted concentrations (MPC) in fish meat intended for human consumption, as established by Serbian national legislation [30], and the European Union [31].

\section{Results and Discussion}

In order to check the validity of the measurements, DORM 4 reference material was used and certified, and observed values are given in Table 1 . The recovery was between $93.25 \%-108.82 \%$. Arsenic and trace element con-

Table 1. Certified element concentration in reference material DORM 4.

\begin{tabular}{|c|c|c|c|}
\hline Element & $\begin{array}{c}\text { Certified } \\
\left(\mathrm{mg} \cdot \mathrm{kg}^{-1}\right)\end{array}$ & $\begin{array}{c}\text { Observed } \\
\left(\mathrm{mg} \cdot \mathrm{kg}^{-1}\right)\end{array}$ & $\begin{array}{c}\text { Recovery } \\
(\%)\end{array}$ \\
\hline $\mathrm{As}$ & $6.80 \pm 0.64$ & $6.52 \pm 0.33$ & 95.88 \\
\hline $\mathrm{Sn}$ & $0.056 \pm 0.010$ & $0.06 \pm 0.064$ & 107.14 \\
\hline $\mathrm{Ni}$ & $1.36 \pm 0.22$ & $1.48 \pm 0.17$ & 108.82 \\
\hline $\mathrm{Co}$ & - & - & - \\
\hline $\mathrm{Al}$ & - & - & - \\
\hline $\mathrm{Se}$ & $3.56 \pm 0.34$ & $3.32 \pm 0.35$ & 93.25 \\
\hline $\mathrm{Fe}$ & $341 \pm 27$ & $333.96 \pm 25.87$ & 97.93 \\
\hline
\end{tabular}


Table 2. Mean concentrations ( $\mathrm{mg} \cdot \mathrm{kg}^{-1}$ ) and associated standard deviations (means $\pm \mathrm{SD}$ ) of arsenic and other trace elements in the muscle (M), liver (L), and gills (G) of pikeperch, catfish, and pike, and in the muscle of Prussian carp and freshwater bream from Bovan Reservoir.

\begin{tabular}{|c|c|c|c|c|c|c|}
\hline Elements & Tissues & $\begin{array}{l}\text { Pikeperch } \\
(\text { mean } \pm \text { SD })\end{array}$ & Catfish $($ mean \pm SD) & Pike (mean \pm SD) & $\begin{array}{l}\text { Prussian carp } \\
(\text { mean } \pm \text { SD })\end{array}$ & $\begin{array}{l}\text { Freshwater bream } \\
\quad(\text { mean } \pm \mathrm{SD})\end{array}$ \\
\hline \multirow{3}{*}{ As } & $\mathrm{M}$ & $0.003 \pm 0.006^{\mathrm{a} A}$ & $0.002 \pm 0.002^{\mathrm{aA}}$ & $0.001 \pm 0.000^{\mathrm{aA}}$ & $0.003 \pm 0.001^{\mathrm{A}}$ & $0.002 \pm 0.000^{\mathrm{A}}$ \\
\hline & $\mathrm{L}$ & $0.004 \pm 0.003^{\mathrm{aB}}$ & $0.001 \pm 0.000^{\mathrm{aA}}$ & $0.002 \pm 0.001^{\mathrm{aA}}$ & - & - \\
\hline & G & $0.002 \pm 0.002^{\mathrm{aA}}$ & $0.002 \pm 0.001^{\mathrm{aA}}$ & $0.002 \pm 0.000^{\mathrm{aA}}$ & - & - \\
\hline \multirow{3}{*}{$\mathrm{Sn}$} & $\mathrm{M}$ & $0.027 \pm 0.006^{\mathrm{aA}}$ & $0.032 \pm 0.008^{\mathrm{bA}}$ & $0.032 \pm 0.002^{\mathrm{a} A}$ & $0.026 \pm 0.001^{\mathrm{A}}$ & $0.028 \pm 0.015^{\mathrm{A}}$ \\
\hline & $\mathrm{L}$ & $0.154 \pm 0.282^{\mathrm{bB}}$ & $0.041 \pm 0.008^{\mathrm{bA}}$ & $0.079 \pm 0.057^{\mathrm{aA}}$ & - & - \\
\hline & $\mathrm{G}$ & $0.039 \pm 0.053^{\mathrm{aB}}$ & $0.008 \pm 0.006^{\mathrm{aA}}$ & $0.027 \pm 0.010^{\mathrm{aB}}$ & - & - \\
\hline \multirow{3}{*}{$\mathrm{Ni}$} & $\mathrm{M}$ & $0.049 \pm 0.033^{\mathrm{aA}}$ & $0.039 \pm 0.018^{\mathrm{aA}}$ & $0.026 \pm 0.005^{\mathrm{aA}}$ & $0.038 \pm 0.010^{\mathrm{A}}$ & $0.050 \pm 0.037^{\mathrm{A}}$ \\
\hline & $\mathrm{L}$ & $0.036 \pm 0.013^{\mathrm{aA}}$ & $0.026 \pm 0.004^{\mathrm{aA}}$ & $0.037 \pm 0.017^{\mathrm{aA}}$ & - & - \\
\hline & $\mathrm{G}$ & $0.042 \pm 0.014^{\mathrm{aA}}$ & $0.043 \pm 0.022^{\mathrm{aA}}$ & $0.051 \pm 0.017^{\mathrm{aA}}$ & - & - \\
\hline \multirow{3}{*}{ Co } & $\mathrm{M}$ & $0.004 \pm 0.009^{\mathrm{aA}}$ & $0.001 \pm 0.000^{\mathrm{aA}}$ & $0.001 \pm 0.000^{\mathrm{aA}}$ & $0.003 \pm 0.004^{\mathrm{A}}$ & $0.014 \pm 0.000^{\mathrm{A}}$ \\
\hline & $\mathrm{L}$ & $0.053 \pm 0.027^{\mathrm{bB}}$ & $0.045 \pm 0.025^{\mathrm{bB}}$ & $0.007 \pm 0.003^{\mathrm{a} A}$ & - & - \\
\hline & G & $0.002 \pm 0.003^{\mathrm{aA}}$ & $0.007 \pm 0.005^{\mathrm{aA}}$ & ND & - & - \\
\hline \multirow{3}{*}{$\mathrm{Al}$} & $\mathrm{M}$ & $2.49 \pm 3.41^{\mathrm{aC}}$ & $1.93 \pm 1.64^{\mathrm{aB}}$ & $0.361 \pm 0.188^{\mathrm{aA}}$ & $2.68 \pm 1.50^{\mathrm{C}}$ & $7.37 \pm 7.71^{\mathrm{D}}$ \\
\hline & $\mathrm{L}$ & $3.73 \pm 5.923^{\mathrm{aA}}$ & $2.66 \pm 5.54^{\mathrm{aA}}$ & $12.38 \pm 13.22^{\mathrm{cB}}$ & - & - \\
\hline & G & $7.81 \pm 6.66^{\mathrm{bA}}$ & $22.65 \pm 21.30^{\mathrm{bB}}$ & $7.34 \pm 2.60^{\mathrm{bA}}$ & - & - \\
\hline \multirow{3}{*}{$\mathrm{Se}$} & $\mathrm{M}$ & $0.091 \pm 0.052^{\mathrm{aA}}$ & $0.142 \pm 0.049^{\mathrm{aB}}$ & $0.170 \pm 0.022^{\mathrm{aB}}$ & $0.237 \pm 0.081^{\mathrm{C}}$ & $0.258 \pm 0.050^{\mathrm{C}}$ \\
\hline & $\mathrm{L}$ & $0.306 \pm 0.112^{\mathrm{bA}}$ & $0.509 \pm 0.143^{\mathrm{bB}}$ & $0.348 \pm 0.090^{\mathrm{bA}}$ & - & - \\
\hline & G & $0.143 \pm 0.038^{\mathrm{aA}}$ & $0.142 \pm 0.037^{\mathrm{aA}}$ & $0.158 \pm 0.033^{\mathrm{aA}}$ & - & - \\
\hline \multirow{3}{*}{$\mathrm{Fe}$} & $\mathrm{M}$ & $42.90 \pm 145.37^{\mathrm{bD}}$ & $5.29 \pm 2.14^{\mathrm{aA}}$ & $3.22 \pm 0.39^{\mathrm{aA}}$ & $18.88 \pm 5.26^{\mathrm{C}}$ & $9.86 \pm 5.47^{\mathrm{B}}$ \\
\hline & $\mathrm{L}$ & $66.47 \pm 20.63^{\mathrm{cA}}$ & $57.84 \pm 16.28^{\mathrm{cA}}$ & $162.17 \pm 117.62^{\mathrm{cB}}$ & - & - \\
\hline & $\mathrm{G}$ & $21.82 \pm 6.84^{\mathrm{aA}}$ & $32.76 \pm 12.63^{\mathrm{bB}}$ & $28.49 \pm 2.92^{\mathrm{bB}}$ & - & - \\
\hline
\end{tabular}

Mean values in the same column with different superscripts $(a, b, c)$ significantly differed $(p<0.05)$ between tissues. Mean values in the same row (A, B, C) with different superscripts significantly differed $(\mathrm{p}<0.05)$ between species.

centrations in three analyzed tissues (muscle, liver, gills) of three predatory fish species (pikeperch, catfish, and pike) and in muscle tissue of Prussian carp and freshwater bream are presented in Table 2. There was no unique pattern of distribution of elements in the tissues of the three predatory fish species (pikeperch, catfish, and pike). The distribution pattern of As concentrations in tissues of three predatory fish species were liver $>$ muscle $>$ gills, muscle $>$ gills $>$ liver, and liver $>$ gills $>$ muscle for pikeperch, catfish, and pike, respectively. Sn levels of pikeperch follows the order liver $>$ gills $>$ muscle, whereas for catfish and pike the order was liver $>$ muscle $>$ gills. The distribution pattern of $\mathrm{Ni}$ was different with all three species: muscle $>$ gills $>$ liver; gills $>$ muscle $>$ liver; gills $>$ liver $>$ muscle for pikeperch, catfish and pike, respectively. In the study, Co accumulation was found to be liver $>$ muscle $>$ gills for pikeperch and pike, and liver $>$ gills $>$ muscle for catfish. The order of $\mathrm{Cr}$ accumulation was determined for pikeperch and catfish as gills $>$ liver $>$ muscle, whereas for pike the order was liver
$>$ gills $>$ muscle. In pikeperch Se had the order accumulation muscle $>$ liver $>$ gills, whereas distribution order in catfish and pike was liver $>$ muscle $>$ gills. Fe level of pikeperchs follow the order liver $>$ muscle $>$ gills, whereas for catfish and pike the order was liver $>$ gills $>$ muscle. As shown on Table 2, with the exception of Co, all the other elements have been accumulated in all three tissues that are studied in three predatory fish species. However, Co was absent in gills of pike. Concentrations of elements examined in muscle tissue (Table 2) showed that freshwater bream had the highest tendency for $\mathrm{Ni}, \mathrm{Co}, \mathrm{Al}$, and $\mathrm{Se}$ accumulation, pikeperch had the highest tendency for As and $\mathrm{Fe}$, while catfish and pike had the highest tendency for $\mathrm{Sn}$ accumulation.

The element concentrations in fish varied considerably among tissues in all three predatory species $(\mathrm{p}<0.05)$ (Table 2). $\mathrm{Al}, \mathrm{Co}, \mathrm{Fe}, \mathrm{Sn}$, and $\mathrm{Se}$ varied among tissues in pikeperch and catfish, while $\mathrm{Al}, \mathrm{Se}$, and $\mathrm{Fe}$ varied among tissues of pike. However, element concentrations in muscle tissue 
were generally lower than in the liver and gills. In the present study, the highest concentrations of As $\left(0.004 \mathrm{mg} \cdot \mathrm{kg}^{-1}\right)$, Sn $\left(0.154 \mathrm{mg} \cdot \mathrm{kg}^{-1}\right)$, and Co $\left(0.053 \mathrm{mg} \cdot \mathrm{kg}^{-1}\right)$ were observed in the liver of pikeperch. The highest concentrations of $\mathrm{Ni}$ $\left(0.051 \mathrm{mg} \cdot \mathrm{kg}^{-1}\right)$ and $\mathrm{Fe}\left(162.17 \mathrm{mg} \cdot \mathrm{kg}^{-1}\right)$ were observed in gills and liver of pike, respectively, while the highest concentrations of $\mathrm{Al}\left(22.65 \mathrm{mg} \cdot \mathrm{kg}^{-1}\right)$ and $\mathrm{Se}\left(0.509 \mathrm{mg} \cdot \mathrm{kg}^{-1}\right)$ were observed in gills and liver of catfish, respectively. The highest element concentrations are accumulated in metabolically active tissues such as liver and gills, while muscles commonly have lower element concentrations. Such a pattern has been observed in a number of other studies covering a wide spectrum of fish species [3, 7, 25, 32-40].

In our study the highest concentration of As was determined in liver (only in pikeperch samples) which is in accordance with results of Lenhardt et al. [25] and $\mathrm{Al}$ Sayegh Petkovšek et al. [41], who found the highest concentrations of As in liver and gills. For other examined species As is uniformly distributed among tissues, as seen in study of Has-Shön et al. [42]. The detected concentrations of As in pikeperch muscle samples $\left(0.003 \mathrm{mg} \cdot \mathrm{kg}^{-1}\right.$ ww) were higher than in samples from Gruža Reservoir (ND - not detected) [26], but lower than in samples from the Danube River $\left(0.17 \mu \mathrm{g} \cdot \mathrm{g}^{-1} \mathrm{dw}\right)$ [27] and $\left(0.032 \mu \mathrm{g} \cdot \mathrm{g}^{-1}\right.$ $\mathrm{dw}$ ) [43]. As concentrations in catfish muscle samples $\left(0.002 \mathrm{mg} \cdot \mathrm{kg}^{-1} \mathrm{ww}\right)$ were lower than in samples from Gruža Reservoir (0.095 $\left.\mathrm{mg} \cdot \mathrm{kg}^{-1} \mathrm{ww}\right)$ [26] and from the Danube $\left(0.22 \mu \mathrm{g} \cdot \mathrm{g}^{-1} \mathrm{dw}\right)$ [27] and $\left(0.22 \mu \mathrm{g} \cdot \mathrm{g}^{-1} \mathrm{dw}\right)$ [43]. Muscle samples from Prussian carp $\left(0.003 \mathrm{mg} \cdot \mathrm{kg}^{-1} \mathrm{ww}\right)$ had lower As concentrations than samples from Gruža Reservoir $(0.106$ $\mathrm{mg} \cdot \mathrm{kg}^{-1}$ ww) [26] and from the Danube $\left(0.031 \mu \mathrm{g} \cdot \mathrm{g}^{-1} \mathrm{dw}\right)$ [43]. As concentrations in freshwater bream muscle samples $\left(0.002 \mathrm{mg} \cdot \mathrm{kg}^{-1} \mathrm{ww}\right)$ were higher than in samples from Gruža Reservoir (ND - not detected) [26], but lower than in samples from Šalek lakes (0.04 $\left.\mathrm{mg} \cdot \mathrm{kg}^{-1} \mathrm{ww}\right)$ [41] and from the Danube $\left(0.035 \mu \mathrm{g} \cdot \mathrm{g}^{-1} \mathrm{dw}\right)$ [43].

$\mathrm{Ni}$ is essential for normal growth and reproduction in animals and humans, but shows a carcinogenic effect when consumed in high amounts. Ni concentrations were the highest in liver samples as in the studies of Jaric et al. [7], Nabavi et al. [44], and Yilmaz et al. [45]. The detected concentrations of $\mathrm{Ni}$ in pikeperch muscle samples $(0.049$ $\mathrm{mg} \cdot \mathrm{kg}^{-1} \mathrm{ww}$ ) were lower than in samples from the Caspian Sea $\left(1.77 \mu \mathrm{g} \cdot \mathrm{g}^{-1} \mathrm{ww}\right)$ [44]. The detected concentrations of $\mathrm{Ni}$ in Prussian carp muscle samples $\left(0.038 \mathrm{mg} \cdot \mathrm{kg}^{-1} \mathrm{ww}\right)$ were lower than in samples from Işikli Dam Lake and Karacaören Dam Lake (1.57 $\left.\mu \mathrm{g} \cdot \mathrm{g}^{-1} \mathrm{dw}\right)$ [46], but higher than in samples from Enne Dame Lake (ND - not detected) [10].

Yilmaz et al. [45] found the highest concentrations of Co in liver samples, as seen in our study. We observed that catfish had the highest concentrations of Co in gills compared to other species, which is in accordance with the findings of Subotić et al. [27]. Co concentrations in Prussian carp muscle samples $\left(0.003 \mathrm{mg} \cdot \mathrm{kg}^{-1}\right)$ were lower than in samples from Işikli Dam Lake and Karacaören Dam Lake (2.80 $\mathrm{mg} \mu \mathrm{g} \cdot \mathrm{g}^{-1} \mathrm{dw}$ ) [46], but higher than in samples from Enne Dame Lake (ND - not detected) [10]. Muscle samples from pikeperch $\left(0.004 \mathrm{mg} \cdot \mathrm{kg}^{-1} \mathrm{ww}\right)$ and catfish $\left(0.003 \mathrm{mg} \cdot \mathrm{kg}^{-1} \mathrm{ww}\right)$ had higher concentrations of Co than samples from the Danube $\left(0.001 \mu \mathrm{g} \cdot \mathrm{g}^{-1} \mathrm{dw}\right.$ for both species) [27].

The highest $\mathrm{Al}$ concentrations were found in gills, which are in line with previous studies of Višnjić-Jeftić et al. [6], Jarić et al. [7], Lenhardt et al. [25], and Sunjog et al. [47], but not in line with Saygi et al. [48], who found the highest concentrations of $\mathrm{Al}$ in liver. Muscle samples from catfish $\left(1.93 \mathrm{mg} \cdot \mathrm{kg}^{-1} \mathrm{ww}\right)$ had higher concentrations of Al than Danube samples (ND - not detected) [25], but lower than other samples from the Danube $\left(7.50 \mu \mathrm{g} \cdot \mathrm{g}^{-1}\right.$ dw) [27]. Al concentrations in freshwater bream (7.37 $\mathrm{mg} \cdot \mathrm{kg}^{-1} \mathrm{ww}$ ) were higher than in from Danube samples (ND - not detected) [25], while concentrations of Al in pikeperch muscle samples $\left(2.49 \mathrm{mg} \cdot \mathrm{kg}^{-1} \mathrm{ww}\right)$ were lower than in Danube samples $\left(7.50 \mu \mathrm{g} \cdot \mathrm{g}^{-1} \mathrm{dw}\right)$ [27].

An essential trace element, selenium, is important for mammals, birds, and fish. Selenium compounds also are capable of protecting from the toxicity of heavy metals such as cadmium and mercury. Se reached the maximum concentrations in liver, which is in accordance with finding of Jarić et al. [7]. Our results for Se (observing the highest concentrations in liver of catfish compared to other species) contradict the findings of Subotić et al. [27], who found that pikeperch had the highest concentrations of Se of all analyzed species (pikeperch, catfish, common carp, gobies). We also detected concentrations of $\mathrm{Se}$ in pikeperch muscle samples $\left(0.091 \mathrm{mg} \cdot \mathrm{kg}^{-1} \mathrm{ww}\right)$ and in catfish muscle samples $\left(0.142 \mathrm{mg} \cdot \mathrm{kg}^{-1} \mathrm{ww}\right)$, which were lower than in pikeperch and catfish muscle samples from the Danube (0.83 and $0.68 \mu \mathrm{g} \cdot \mathrm{g}^{-1} \mathrm{dw}$, respectively) [27]. Kenšová et al. [33] pointed to piscivorius fish species accumulating the highest concentrations of Se, which is not the case in our study. In contrast, in our study freshwater bream had the highest concentrations of Se in muscle $\left(0.258 \mathrm{mg} \cdot \mathrm{kg}^{-1} \mathrm{ww}\right)$ compared to other fish.

Rajkowska et al. [37], Yilmaz et al. [45], and SzarekGwiazda and Amirowicz [49] pointed to the liver as a storage organ for $\mathrm{Fe}$, and such is the case in our study. The detected concentrations of $\mathrm{Fe}$ in pikeperch muscle samples (42.90 mg $\left.\mathrm{kg}^{-1} \mathrm{ww}\right)$ were higher than in samples from Gruža Reservoir (3.12 $\mathrm{mg} \cdot \mathrm{kg}^{-1}$ ww) [26], and from the Caspian Sea $\left(2.79 \mu \mathrm{g} \cdot \mathrm{g}^{-1} \mathrm{ww}\right)$ [44]. Fe concentrations in catfish muscle samples $\left(5.29 \mathrm{mg} \cdot \mathrm{kg}^{-1} \mathrm{ww}\right)$ were lower than in samples from the Gruža Reservoir (7.4 $\mathrm{mg} \cdot \mathrm{kg}^{-1}$ ww) [26], but higher than in Danube samples (ND - not detected) [25]. The detected concentrations of Fe in freshwater bream muscle samples $\left(9.86 \mathrm{mg} \cdot \mathrm{kg}^{-1} \mathrm{ww}\right)$ were higher than in samples from Gruža Reservoir (2.8 $\left.\mathrm{mg} \cdot \mathrm{kg}^{-1} \mathrm{ww}\right)$ [26], and from Lake Insko and Wisola (1.5 and $1.3 \mu \mathrm{g} \cdot \mathrm{g}^{-1} \mathrm{ww}$, respectively) [37]. Muscle samples from pike had higher concentrations of Fe (3.22 $\left.\mathrm{mg} \cdot \mathrm{kg}^{-1}\right)$ than samples from Lake Insko and Wisola (1.4 and $0.8 \mu \mathrm{g} \cdot \mathrm{g}^{-1} \mathrm{ww}$, respectively) [37].

The Kruskal-Wallis test revealed significant differences between fish species with regard to element levels in muscle for $\mathrm{Al}, \mathrm{Se}$, and $\mathrm{Fe}(\mathrm{p}<0.05)$, in gills for $\mathrm{Al}, \mathrm{Sn}$, and $\mathrm{Fe}$ $(\mathrm{p}<0.05)$, and in liver for $\mathrm{As}, \mathrm{Sn}, \mathrm{Co}, \mathrm{Al}, \mathrm{Fe}$, and $\mathrm{Se}$ $(\mathrm{p}<0.05)$ (Table 2). Post hoc inter-group comparisons between pairs of species for levels of elements in specific 
tissues, performed by the non-parametric Mann-Whitney test, for muscle showed that freshwater bream had significantly higher levels of $\mathrm{Al}$ and Se, while pikeperch had significantly higher levels of $\mathrm{Fe}$ compared to other species. Gills showed the least differences for all tested elements. Catfish was different by the lowest levels of Sn and the highest levels of $\mathrm{Al}$ and $\mathrm{Fe}$. For the liver, this test showed that pikeperch had significantly higher levels of As and Sn compared to other species. Pike had significantly higher levels of $\mathrm{Al}$ and $\mathrm{Fe}$, but significantly lower levels of $\mathrm{Co}$, while catfish had significantly higher levels of Se compared to other species. The accumulation patterns tend to vary among species based on their behavior and feeding habits [38], which are in accordance with the results in this study. Freshwater bream diverged from the other four species based on element concentrations in muscle, which could be a result of its diet (chironomid larvae and other benthic organisms). On the other hand, catfish diverged from the other predator species based on element concentrations in gills, which might be explained with its different behavioral patterns (situated in a littoral zone, in mud). This indicates that the element levels detected in organs seem to reflect the pollution levels of sediment and its biota, rather than the prevailing pollution state of the water.

Although Al-Yousuf et al. [50] reported that the concentrations of elements in fish tissues are generally related to the age of a fish and consequently its size and length, there were only a few significant correlations between element accumulation and fish size and weight in our study. In the muscle of pikeperch, Se had strong negative correlation with fish weight (correlation coeff. $-0.648, \mathrm{p}<0.05$ ). There were recorded the most correlations between the element accumulation and fish size and weight in the tissues of pike. As, $\mathrm{Al}, \mathrm{Ni}$ in muscle, and As in liver of pike had a positive correlation with fish size and weight (correlation coeff. $1.00, \mathrm{p}<0.05$ ), since $\mathrm{Se}$, and $\mathrm{Sn}$ in liver, and $\mathrm{Al}$ in gills of pike had significantly negative correlation with fish size and weight (correlation coeff. $-1.00, \mathrm{p}<0.05$ ). In the muscle of catfish $\mathrm{Ni}$ had strong negative correlation with fish size (correlation coeff. $-0.943, \mathrm{p}<0.05$ ). Ni had a strong positive correlation with fish size and weight (correlation coeff. 1.00 and 1.00 , respectively, $\mathrm{p}<0.05$ ), while Se had a strong negative correlation with fish size and weight (correlation coeff. -1.00 and -1.00 , respectively, $\mathrm{p}<0.05$ ) in the muscle of freshwater bream. Fe and As were positively correlated with fish size and weight (correlation coeff. 1.00 and 1.00, respectively, $\mathrm{p}<0.05$ ) in the muscle of Prussian carp. Such differences in results could probably be explained by differences in life histories of assessed fish species, as well as by differences in their habitats. Canli and Atli [51] indicated that the negative relationships between fish size and element levels could be due to differences in metabolic activity between younger and older fish. Our findings were similar to previous studies on the same and other fish species. For instance, Rajkowska et al. [37] observed positive fish size dependent relationship for Fe in gills of pike (Esox lucius), whereas in the case of freshwater bream (Abramis brama) such dependence was observed in liver. According to Tekin-Özan et al. [52] sig- nificant negative relationships were found between fish length and weight related to As and Fe concentrations in muscle, liver, and gills of carp (Cyprinus carpio). In a study by Lenhardt et al. [25], concentrations of Al in liver of silver carp (Hypophthalmichthys molitrix) increased with fish size and weight.

For most examined elements there are no national [30] and European [31] prescribed maximum permitted concentrations (MPC). The levels of As did not exceed the MPC prescribed by the National Regulation of the Republic of Serbia [30], which is $2 \mathrm{mg} \cdot \mathrm{kg}^{-1}$ ww. However, comparison of the national prescribed MPC for Fe (30 mg. $\left.\mathrm{kg}^{-1} \mathrm{ww}\right)$ indicated that one sample of pikeperch muscle, all pikeperch, catfish, and pike liver samples, and two catfish, and pike gills samples had elevated concentrations. This indicates that the meat of studied species should be safe for utilization in human diet. However, other tissues, which are sometimes also utilized in human diet, should therefore be omitted.

\section{Conclusions}

The element concentrations in fish varied considerably among tissues in all three predatory species. However, element concentrations in muscle tissue were generally lower than in the liver and gills. Concentrations of elements examined in muscle tissue showed that freshwater bream had the highest tendency for $\mathrm{Ni}, \mathrm{Co}, \mathrm{Al}$, and Se accumulation, pikeperch had the highest tendency for As, and Fe, while catfish and pike had the highest tendency for Sn accumulation. Freshwater bream diverged from the other four species based on element concentrations in muscle, which could be a result of its diet (chironomid larvae and other benthic organisms). On the other hand, catfish diverged from the other predatory species based on element concentrations in gills, which might be explained with its different behavioral patterns (situated in a littoral zone, in mud). This indicates that the element levels detected in organs seems to reflect the pollution level of sediment and its biota, rather than the prevailing pollution state of the water.

There were a few significant correlations between the element accumulation and fish size and weight in our study, with the most recorded correlations in the tissues of pike, which could probably be explained by life histories as well as by habitat of this species.

To conclude, the obtained results indicate that the Bovan Reservoir is polluted with $\mathrm{Fe}$, accordingly posing a risk for the human consumption of these fish species. Regular analysis of fish meat quality is considered a very important measure because of the distribution of fish from this reservoir directly to consumers.

\section{Acknowledgements}

This investigation was supported by the Ministry of Science and Technological Development of the Republic of Serbia as part of project No. 31011. 


\section{References}

1. PAPAGIANNIS I., KAGALOU I., LEONARDOS J., PETRIDIS D., KALFAKAKOU V. Copper and zinc in four freshwater fish species from Lake Pamvotis (Greece). Environ. Int. 30, (3), 362, 2004.

2. ASHRAF W, SEDDIGI Z, ABULKIBASH A, KHALID M. Levels of selected metals in canned fish consumed in Kingdom of Saudi Arabia. Environ. Monit. Assess. 117, (13), 279, 2006.

3. DURAL M., GÖKSU L.Z.M., ÖZAK A.A., DERÍCÍ B. Bioaccumulation of some heavy metals in different tissues of Dicentrarchus labrax L, 1758, Sparus aurata L, 1758 and Mugil cephalus L, 1758 from the Çamlik Lagoon of the Eastern Cost of Mediterranean (Turkey). Environ. Monit. Assess. 118, 74, 2006.

4. LÓPEZ ALONSO M., PRIETO MONTAÑA F., MIRANDA M., CASTILLO C., HERNÁNDEZ L., LUIS BENEDITO J. Interactions between toxic $(\mathrm{As}, \mathrm{Cd}, \mathrm{Hg}$ and $\mathrm{Pb}$ ) and nutritional essential $(\mathrm{Ca}, \mathrm{Co}, \mathrm{Cr}, \mathrm{Cu}, \mathrm{Fe}, \mathrm{Mn}, \mathrm{Mo}, \mathrm{Ni}, \mathrm{Se}$, $\mathrm{Zn}$ ) elements in the tissues of cattle from NW Spain. Biometals 17, (4), 397, 2004.

5. BENSON N.U., ESSIEN J. P., WILLIAMS A.B., BASSEY D.E. Mercury accumulation in fishes from tropical aquatic ecosystems in the Niger Delta, Nigeria. Curr. Scie. 92, (6), 785, 2007.

6. VISNJIC-JEVTIC Z., JARIC I., JOVANOVIC LJ., SKORIC S., SMEDEREVAC-LALIC M., NIKCEVIC M., LENHARDT M. Heavy metal and trace element accumulation in muscle, liver and gills of the Pontic shad (Alosa immaculata Bennet 1835) from the Danube River (Serbia). Microchem. J. 95, (2), 344, 2010.

7. JARIĆ I., VIŠNJIĆ-JEVTIĆ Ž., CVIJANOVIĆ G., JOVANOVIĆ LJ., SKORIĆ S., LENHARDT M. Determination of differential heavy metal and trace element accumulation in liver, gills, intestine and muscle of starlet (Acipenser ruthenus) from Danube River in Serbia by ICPOES. Microchem. J. 98, (1), 81, 2011.

8. KLAVINS M., POTAPOVICS O., RODINOV V. Heavy metals in fish from lakes in Latvia: concentrations and trends of changes. B Environ. Contam. Tox. 82, (1), 100, 2009.

9. PLOETZ D.M., FITTS B.E., RICE T.M. Differential accumulation of heavy metals in muscle and liver of marine fish, (King Mackerel, Scomberomorus cavalla Cuvier) from the Northern Gulf of Mexico, USA. B. Environ. Contam. Tox. 78, 127, 2007.

10. UYSAL K., KÖSE E., BÜLBÜL M., DÖNMEZ M., ERDOGAN Y., KOYUN M., OMEROGLU C., OZMAL F. The comparison of heavy metal accumulation ratios of some fish species in Enne Dame Lake (Kütahya/Turkey). Environ. Monit. Assess. 157, (1-4), 362, 2009.

11. COSTA S.C., HARTZ S.M. Evaluation of trace metals (cadmium, chromium, copper and zinc) in tissues of a commercially important fish (Leporinus obtusidens) from Guaíba Lake, Southern Brazil. Braz. Arch. Biol. Techn. 52, (1), 250, 2009.

12. HAS-SCHÖN E., BOGUT I., STRELEC I. Heavy metal profile in five fish species included in human diet, domiciled in the end flow of river Neretva (Croatia). Arch. Environ. Con. Tox. 50, (4), 551, 2006.

13. FARKAS A., SALÁNKI J., VARANKA I. Heavy metal concentrations in fish of Lake Balaton. Lakes and Reservoirs: Research and Menagement 5, (4), 279, 2000.
14. JEZIERSKA B., WITESKA M. The metal uptake and accumulation in fish living in polluted waters. In: TWARDOWSKA I., ALLEN H.E., HÄGGBLOM M.M., STEFANIAK E. (Eds) Viable methods of soil and water pollution monitoring, protection and remediation. Springer, New York, pp. 3-23, 2006.

15. KORN M.G., DOS SANTOS G.L., ROSA S.M., TEIXEIRA L.S., DE OLIVEIRA P.V. Determination of cadmium and lead in cetacean Dolphinidae tissue from the coast of Bahia state in Brazil by GFAAS. Microchem. J. 96, (1), 16, 2010.

16. SAEI-DEHKORDI S.S., FALAH A.A. Determination of copper, lead, cadmium and zinc content in commercially valuable fish species from the Persian Gulf using derivative potentiometric stripping analysis. Microchem. J. 98, (1), 162, 2011.

17. AGAH H., LEEMAKERS M., GAO Y., FATEMI S. M., KATAL M. M., BAEYENS W., ELSKENS M. Mercury accumulation in fish species from the Persian Gulf and in human hair from fishermen. Environ. Monit. Assess. 169, (1-4), 216, 2010.

18. TUZEN M. Toxic and essential trace elemental contents in fish species from the Black Sea, Turkey. Food Chem. Toxicol. 47, (8), 1790, 2009.

19. LEKIC-ARANDJELOVIC I., KILIBARDA N., DIMITRIJEVIC M., KARABASIL N. Fish consumption in the world, the European Union and Serbia. Proceedings and abstracts of the $20^{\text {th }}$ veterinarian conference, Zlatibor, Serbia, 97, 2008.

20. ANTONIJEVIC B., MATTHYS C., SIOEN I., BILAU M., VAN CAMP J., WILLEMS J.L., DE HENAUW S. Simulated impact of a fish based shift in the population n-3 fatty acids intake on exposure to dioxins and dioxin-like compounds. Food Chem. Toxicol. 45, (11), 2286, 2007.

21. PIENIAK Z., VERBEKE W., SCHOLDERER J. Healthrelated beliefs and consumer knowledge as determinants of fish consumption. J Human Nutr Diet. 23, (5), 488, 2010.

22. RUXTON C.H.S. The benefits of fish consumption. Nutr. Bull. 36, 19, 2011.

23. EBRAHIMPOUR M., MUSHRIFAH I. Seasonal variation of cadmium, copper, and lead concentrations in fish from a freshwater lake. Biol. Trace Elem. Res. 138, (1-3), 201, 2010.

24. POLEKSIC V., LENHARDT M., JARIC I., DJORDJEVIC D., GACIC Z., CVIJANOVIC G., RASKOVIC B. Liver, gills and skin histopathology and heavy metals content of the Danube starlet (Acipenser ruthenus Linnaeus, 1758). Environ. Toxicol. Chem. 29, (3), 521, 2010.

25. LENHARDT M., JARIĆ I., VIŠNJIĆ-JEVTIĆ Ž., SKORIĆ S., GAČIĆ Z., PUCAR M., HEGEDIŠ A. Concentrations of 17 elements in muscle, gills, liver and gonads of five economically important fish species from the Danube River. Knowl. Managt. Aquatic Ecosyst. 407, 2012.

26. MILOŠKOVIĆ A., BRANKOVIĆ S., SIMIĆ V., KOVAČEVIĆ S., ĆIRKOVIĆ M., MANOJLOVIĆ D. The accumulation and distribution of metals in water, sediment, aquatic macrophytes and fishes of the Gruža Reservoir, Serbia. B. Environ. Contam. Tox. 90, (5), 569, 2013.

27. SUBOTIĆ S., SPASIĆ S., VIŠNJIĆ-JEFTIĆ Z., HEGEDIŠ A., KRPO-ĆETKOVIĆ J., MIĆKOVIĆ B., SKORIĆ S., LENHARDT M. Heavy metal and trace element bioaccumulation in target tissues of four edible fish species from the Danube River (Serbia). Ecotoxicol Environ Saf. 98, 202, 2013. 
28. ZLATKOVIĆ S., ŠABIĆ D., MILINČIĆ M., KNEŽEVIĆVUKČEVIĆ J., STANKOVIĆ S. Geographical and biological analysis of the water quality of Bovan Lake, Serbia. Arch. Biol. Sci. 62, (4), 1087, 2010.

29. LENHARDT M., MARKOVIC G., HEGEDIS A., MALETIN S., CIRKOVIC M., MARKOVIC Z. Non-native and translocated fish species in Serbia and their impact on the native ichthyofauna. Rev. Fish Biol. Fisher. 21, 421, 2011.

30. Official Gazzette of FRY, No. 28/2011. Regulation on quantity of pesticides, metals, metalloids, and other toxic substances, chemotherapeutics, anabolics, and other substances which can be found in food [In Serbian].

31. Official Journal of the European Communities. Commission Regulation (EC) No. 466/2001, of 8 March 2001. setting maximum levels for certain contaminants in foodstuffs.

32. ERDOĞRUL O., ERBILIR F. Heavy metals and trace elements in various fish samples from Sir Dam Lake, Kahramanmaraş, Turkey. Environ. Monit. Assess. 130, (13), 379, 2007.

33. KENŠOVÁ R., ČELECHOVSKÁ O., DOUBRAVOVÁ J., SVABODOVÁ Z. Concentrations of metals in tissue of fish from the Věstonice Reservoir. Acta Vet. Brno 79, (2), 345, 2010.

34. MALIK N., BISWAS A.K., QURESHI T.A., BORANA K., VIRHA R. Bioaccumulation of heavy metals in fish tissues of a freshwater lake of Bhopal. Environ. Monit. Assess. 160, (1-4), 276, 2010.

35. STORRELI M. M., BARONE G., STORELLI A., MARCOTRIGIANO G.O. Trace metals in tissues of Mugilids (Mugil auratus, Mugil capito, and Mugil labrosus) from the Mediterranean Sea. B. Environ. Contam. Tox. 77, (1), 50, 2006.

36. RASHED M.N. Monitoring of environmental heavy metals in fish from Nasser Lake. Environ Int. 27, (1), 33, 2001.

37. RAJKOWSKA M., PROTASOWICKI M. Distribution of metals (Fe, $\mathrm{Mn}, \mathrm{Zn}, \mathrm{Cu}$ ) in fish tissues in two lakes of different trophy in Northwestern Poland. Environ. Monit. Assess. 185, (4), 3502, 2013.

38. AGAH H., LEERMAKERS M., ELSKENS M., FATEMI S.M., BAEYENS W. Accumulation of trace metals in the muscle and liver tissues of five fish species from the Persian Gulf. Environ. Monit. Assess. 157, (1-4), 514, 2009.

39. CALTA M., CANPOLAT Ö. The comparison of three cyprinid species in terms of heavy metals accumulation in some tissues. Water Environ. Res. 78, (5), 551, 2006.

40. GÜL A., YILMAZ M., BENZER S., TAȘDEMIR L. Investigation of zinc, copper, lead and cadmium accumulation in the tissues of Sander lucioperca (L., 1758) living in Hirfanli Dam Lake, Turkey. B. Environ. Contam. Tox. 87, (3), 266, 2011.
41. AL SAYEGH PETKOVŠEK S., MAZEJ GRUDNIK Z., POKORNY B. Heavy metals and arsenic concentrations in ten fish species from the Šalek lakes (Slovenia): assessment of potential human health risk due to fish consumption. Environ. Monit. Assess. 184, (5), 2662, 2012.

42. HAS-SCHÖN E., BOGUT I., RAJKOVIĆ V., BOGUT S., CACIĆ M., HORVATIĆ J. Heavy metal distribution in tissues of six fish species included in human diet, inhabiting freshwaters of the Nature Park "Hutovo Blato" (Bosnia and Herzegovina). Arch. Environ. Con. Tox. 54, (1), 83, 2007.

43. ZRNČIĆ S., ORAIĆ D., ĆALETA M., MIHALJEVIĆ Ž., ZANELLA D., BILANDŽIĆ N. Biomonitoring of heavy metals in fish from the Danube River. Environ. Monit. Assess. 185, (2), 1198, 2013.

44. NABAVI S.F., NABAVI S.M., LATIFI A.M., ESLAMI S., EBRAHIMZADEH M.A. Determination of trace elements level of pikeperch collected from the Caspian Sea. B. Environ. Contam. Tox. 88, (3), 405, 2012.

45. YILMAZ A.B., SANGÜN M.K., YAĞLIOĞLU D., TURAN C. Metals (major, essential to non-essential) composition of the different tissues of three demersal fish species from İskenderun Bay, Turkey. Food Chem 123, (2), 415, 2010.

46. KALYONCU L., KALYONCU H., ARSLAN G. Determination of heavy metals and metals levels in five fish species from Işıklı Dam Lake and Karacaören Dam Lake (Turkey). Environ. Monit. Assess. 184, (4), 2235, 2012.

47. SUNJOG K., GAČIĆ Z., KOLAREVIĆ S., VIŠNJIĆJEFTIĆ Ž., JARIĆ I., KNEŽEVIĆ-VUKČEVIĆ J., VUKOVIĆ-GAČIĆ B., LENHARDT M. Heavy metal accumulation and the genotoxicity in barbel (Barbus barbus) as indicators of the Danube river pollution. Sci. World J. Article ID 351074, 6, 2012.

48. SAYGI Y., YIĞIT S. A. Assessment of metal concentrations in two cyprinid fish species (Leuciscus cephalus and Tinca tinca) captured from Yaniçağa Lake, Turkey. B. Environ. Contam. Tox. 89, (1), 90, 2012.

49. SZAREK-GWIAZDA E., AMIROWICH A. Bioaccumulation of trace elements in roach, silver bream, rudd, and perch living in an inundated opencast sulphur mine. Aquat Ecol 40, 236, 2006.

50. AL-YOUSUF M.H., EL-SHAHAWI M.S., AL-GHAIS S.M. Trace metals in liver, skin and muscle of Lethrinus lentjan fish species in relation to body length and sex. Sci. Total Environ. 256, (2-3), 94, 2000.

51. CANLI M., ATLI G. The relationships between heavy metal $(\mathrm{Cd}, \mathrm{Cr}, \mathrm{Cu}, \mathrm{Fe}, \mathrm{Pb}, \mathrm{Zn})$ levels and the size of six Mediterranean fish species. Environ. Pollut. 121, (1), 136, 2003.

52. TEKIN-ÖZAN S., AKTAN N. Relationship of heavy metals in water, sediment and tissues with total length, weight and seasons of Cyprinus carpio L., 1758 from Işikli Lake (Turkey). Pak J. Zool. 44, (5), 1416, 2012. 